\title{
BACTERIOLOGICAL AND MOLECULAR CHARACTERIZATION OF SOME PATHOGENS FROM FAST FOODS
}

\author{
NASHWA, M. ZAKI ${ }^{1}$; NEHAL, M. NABIL ${ }^{3 ;}$ HEGAZY, A. RAMADAN ${ }^{2}$ and \\ NAHLA, S. ELSHATER ${ }^{4}$ \\ ${ }^{1}$ Food Hygiene Dept., Animal Health Research Institute, Mansoura, Egypt \\ ${ }^{2}$ Bacteriology Dept., Animal Health Research Institute, Mansoura, Egypt. \\ ${ }^{3}$ Reference Lab for Quality Control on Poultry Production, Animal Health Research Institute, Gamasa, Egypt. \\ ${ }^{4}$ Reference Lab for Quality Control on Poultry Production, Animal Health Research Institute, Dokki, Egypt.
}

Received: 23 March 2017; Accepted: 12 April 2017

\begin{abstract}
This study was conducted to evaluate the bacteriological status of some fast food and the public health significance of some isolated pathogenic bacteria from their bacteriological and molecular point of view. Sixty random samples of chicken nuggets, beef shawerma and sausage sandwiches (20 samples for each) were collected from different fast food restaurants in Dakahlia Governorate and examined for their bacteriological status. The obtaind results indicated that the mean values of APC count, coliform and Staph. aureus counts of chicken nuggets, beef shawerma and sausage were $9.1 \times 10^{3} \pm 1.2 \times 10^{3} 1.3 \times 10^{4} \pm 3.5 \times 10^{3}$ and $1.2 \times 10^{4} \pm 2.2 \times 10^{3}$; < $10,1.1 \times 10^{3} \pm 1.2 \times 10^{2}$ and $8.5 \times 10^{3} \pm 1.1 \times 10^{3}, 5.6 \times 10^{3} \pm 1.2 \times 10^{3}, 8.7 \times 10^{3} \pm 1.2 \times 10^{3}$ and $6.3 \times 10^{3} \pm 3.1 \times 10^{3}$ respectively. The bacteriological examination of these products showed the presence of one Salmonella isolate ( $S$. Typhimurium) with a percentage of (5\%) and two E. coli isolates with a percentage of (10\%) in 20 meat shawerma samples, meanwhile nuggets and sausage were negative for both Salmonella and E.coli isolation. Eight coagulase positive Staphylococcus aureus were isolated with a percentage of (10\%, 15\% and 15\%) from chicken nuggets, beef shawerma and sausage, respectively. PCR was applied to evaluate the presence of some virulence genes in the isolated Salmonella, E. coli and Staphylococcus aureus. The isolated S. Typhimurium harbored invA and $s t n$ genes. The isolated E.coli showed absence of shiga toxin genes (stx1 and stx2). The examined coagulase positive Staphylococcus aureus showed the presence of different enterotoxin genes (sea, $s e b$, sec, sed and see). The puplic health significance and the possible sourcs of contamination of isolated organisms as well as some recommendations to improve the quality were discussed.
\end{abstract}

Key words: Fast Foods, Pathogens, Virulence genes.

\section{INTRODUCTION}

Nuggets, Shawarma and Sausage are the most ready to eat sandwiches sold in fast food restaurants.

There is an increase in the consumption of ready-toeat fast food because of a changes in social patterns characterized by increased mobility, large numbers of itinerary workers and less family centered activities. Thus, good manufacturing practices of foods taken outside the home such as good sanitation or sanitary measure and proper food handling have been transferred from individuals/families to the food vendor who rarely enforces such practice (Musa and Okande, 2002).

Corresponding author: Dr. NASHWA, M. ZAKI

E-mail address: nashwazaki80@gmail.com

Present address: Food Hygiene Dept., Animal Health Research Institute, Mansoura, Egypt
Sandwiches are manipulated extensively during processing and there for have a potentiality for high bacterial contamination level on the surface and depth of meat so there is an increased risk of pathogens surviving and transferring not only by cross contamination but also through undercooking as in fast food industry (Nimri- Laila et al., 2014).

Microorganisms in fast foods are responsible for many human diseases. e.g Salmonella bacteria which considered a common cause of food borne illness, particularly in undercooked chicken and chicken eggs (Woodward, 1996; Kaneko et al., 1999; Uyttendaele et al., 1999 and Angelillo et al., 2000).

On the other hand Escherichia coli is common, harmless bacteria of the human intestinal flora. However, five groups of E. coli-causing diarrhea in humans and other warm-blooded animals have been identified (Brook et al., 1994; Wasteson, 2001).

Staph.aureus is the most prevalent contagious pathogens, which rapidly and easily transmitted, as 
well as it causes a zoonotic disease which transmitted to human being (Forbes and Weissfield, 2002).

In recent years fast food restaurants have added salads fresh vegetables e.g Onion (Some sauas such as Ketchup and Mayonise). Some foods will be cooked before consumption others will be eaten raw. Contamination of fast foods during processing, and changes in microbial growth patterns during storage, may affect the microflora of these foods quantitatively and qualitatively. The inner tissues of healthy animals are free of microorganisms. However, the surfaces of raw vegetables and meats are contaminated with a variety of microorganisms and this depends on the condition of the raw product, the method of handling, the time and conditions of storage (Wood-Ward, 1996; Odumeru et al., 1997 and Pelczar et al., 2006).

The prevalence of Staphylococcus spp., Escherichia coli, Salmonella spp., on meat, sea foods, vegetable ingredients, chicken shawarmas, raw and cooked foods, raw chicken, beef burger sandwiches, ready-to eat salad vegetables, commercial mayonnaise, frozen chicken, poultry products, it depends on the contamination level of food workers hands (Kaneko et al., 1999 and Pelczar et al., 2006).

The purpose of this study is to determine the bacteriologicale status of nuggets, shawarma and Sausage sandwiches, public health significance of isolated pathogenes and their impact on consumer health.

\section{MATERIALS AND METHODS}

\section{1- Collection of samples:}

A total of 60 random chicken nuggets, beef shawarma and susage sandwiches (20 of each) were collected from different fast food restaurants in Dakahlia governorate. The collected samples were directly transferred to the laboratory to carry out the following bacteriological examination.

\section{2- Bacteriological examination:}

2.1- Preparation of food homogenate: according to technique recommended by (ISO, 6887-2, 2003).

2.2- Total Bacteriological count: Total aerobic plate count: (APHA, 2001) spreading technique using standard plate count agar, incubated at $35^{\circ} \mathrm{C}$ for $48 \mathrm{hr}$.

2.3- Total coliform count: (APHA, 2001) spreading technique using violet red bile (VRB) agar, incubated at $37^{\circ} \mathrm{C}$ for $24 \mathrm{hr}$.

2.4- Staphylococcus aureus count: (FDA, 2002) using Baird-Parker agar plates, incubated at $35{ }^{\circ} \mathrm{C}$ for
48 hr. The suspected Staph. aureus colonies were isolated, purified and confirmed by coagulase test.

2.5- Isolation of Salmonellae (ISO, 6579, 2002): by enrichment in Tetrathionate $\left(37{ }^{\circ} \mathrm{C}\right.$ for $\left.24 \mathrm{hr}\right)$ and rappaport vasiliades at $41.5^{\circ} \mathrm{C}$ for $18 \mathrm{hr}$., platting on XLD, MaCconkey's and Hektone entreic agar at $37^{\circ} \mathrm{C}$ for $24 \mathrm{hr}$. The presumptive colonies were confirmed biochemically and serologically.

2.6- Isolation of $\boldsymbol{E}$. coli according to technique recommended by (ISO, 16649/2, 2001).

3- Detection of virulence genes in Salmonella, $E$. coli and Staphylococcus aureus using PCR.

\section{1- DNA extraction:}

DNA extraction from samples was performed using the QIAamp DNA Mini kit (Qiagen, Germany, $\mathrm{GmbH}$ ) with modifications from the manufacturer's recommendations. Briefly, $200 \mu \mathrm{l}$ of the sample suspension was incubated with $10 \mu \mathrm{l}$ of proteinase $\mathrm{K}$ and $200 \mu \mathrm{l}$ of lysis buffer at $56^{\mathrm{O}} \mathrm{C}$ for $10 \mathrm{~min}$. After incubation, $200 \mu \mathrm{l}$ of $100 \%$ ethanol was added to the lysate. The sample was then washed and centrifuged following the manufacturer's recommendations. Nucleic acid was eluted with $100 \mu$ l of elution buffer provided in the kit.

\section{2- Oligonucleotide Primer:}

Primers used were supplied from Metabion (Germany) are listed in table (1) and table (2).

\section{3- PCR amplification:}

For uniplex PCR, primers were utilized in a $25-\mu 1$ reaction containing $12.5 \mu \mathrm{l}$ of Emerald Amp Max PCR Master Mix (Takara, Japan), $1 \mu$ l of each primer of 20 pmol concentrations, $4.5 \mu \mathrm{l}$ of water, and $6 \mu 1$ of DNA template. For stx1, stx2 duplex PCR, primers were utilized in a 50- $\mu 1$ reaction containing $25 \mu 1$ of Emerald Amp Max PCR Master Mix (Takara, Japan), $1 \mu 1$ of each primer of 20 pmol concentration, $13 \mu 1$ of water, and $8 \mu \mathrm{l}$ of DNA template. The reaction was performed in an Applied biosystem 2720.

\section{4- Analysis of the PCR Products:}

The products of PCR were separated by electrophoresis on $1.5 \%$ agarose gel (Applichem, Germany, GmbH) in $1 \mathrm{x}$ TBE buffer at room temperature using gradients of $5 \mathrm{~V} / \mathrm{cm}$. For gel analysis, $20 \mu 1$ of the uniplex PCR products and $30 \mu 1$ of the duplex PCR products were loaded in each gel slot. Generuler 100 bp ladder (Fermentas, Thermo Scientific, Germany) was used to determine the fragment sizes. The gel was photographed by a gel documentation system (Alpha Innotech, Biometra) and the data was analyzed through computer software. 
Table 1: Primers sequences, target genes, amplicon sizes and cycling conditions.

\begin{tabular}{|c|c|c|c|c|c|c|c|c|}
\hline \multirow[b]{2}{*}{ target } & \multirow[b]{2}{*}{ Primers sequences } & \multirow[b]{2}{*}{$\begin{array}{c}\text { Amplified } \\
\text { segment (bp) }\end{array}$} & \multirow[b]{2}{*}{$\begin{array}{c}\text { Primary } \\
\text { denaturation }\end{array}$} & \multicolumn{3}{|c|}{ Amplification ( 35 cycles) } & \multirow[b]{2}{*}{$\begin{array}{c}\text { Final } \\
\text { extension }\end{array}$} & \multirow[b]{2}{*}{ Reference } \\
\hline & & & & $\begin{array}{c}\text { Secondary } \\
\text { denaturation }\end{array}$ & Annealing & Extension & & \\
\hline stn & $\begin{array}{c}\text { TTG TGT CGC TAT } \\
\text { CAC TGG CAA CC } \\
\text { ATT CGT AAC CCG } \\
\text { CTC TCG TCC }\end{array}$ & 617 & $\begin{array}{l}94^{\circ} \mathrm{C} \\
5 \mathrm{~min} .\end{array}$ & $\begin{array}{l}94^{\circ} \mathrm{C} \\
30 \mathrm{sec} .\end{array}$ & $\begin{array}{l}59^{\circ} \mathrm{C} \\
45 \mathrm{sec} .\end{array}$ & $\begin{array}{l}72^{\circ} \mathrm{C} \\
45 \mathrm{sec}\end{array}$ & $\begin{array}{c}72^{\circ} \mathrm{C} \\
10 \mathrm{~min} .\end{array}$ & $\begin{array}{l}\text { Murugkar } \\
\text { et al., } 2003\end{array}$ \\
\hline$i n v A$ & $\begin{array}{c}\text { GTGAAATTATCGC } \\
\text { CACGTTCGGGCAA } \\
\text { TCATCGCACCGTCA } \\
\text { AAGGAACC }\end{array}$ & 284 & $\begin{array}{l}94^{\circ} \mathrm{C} \\
5 \mathrm{~min} .\end{array}$ & $\begin{array}{l}94^{\circ} \mathrm{C} \\
30 \mathrm{sec} .\end{array}$ & $\begin{array}{l}55^{\circ} \mathrm{C} \\
30 \mathrm{sec}\end{array}$ & $\begin{array}{l}72^{\circ} \mathrm{C} \\
30 \mathrm{sec}\end{array}$ & $\begin{array}{l}72^{\circ} \mathrm{C} \\
7 \mathrm{~min}\end{array}$ & $\begin{array}{c}\text { Oliveira } e t \\
\text { al., } 2003\end{array}$ \\
\hline Stx 1 & $\begin{array}{c}\text { ACACTGGATGATC } \\
\text { TCAGTGG } \\
\text { CTGAATCCCCCTCC } \\
\text { ATTATG } \\
\text { CCATGACAACGGA } \\
\text { CAGCAGTT } \\
\text { CCTGTCAACTGAG } \\
\text { CAGCACTTTG }\end{array}$ & 779 & $\begin{array}{l}94^{\circ} \mathrm{C} \\
5 \mathrm{~min} .\end{array}$ & $\begin{array}{l}94^{\circ} \mathrm{C} \\
30 \mathrm{sec} .\end{array}$ & $\begin{array}{c}58^{\circ} \mathrm{C} \\
45 \mathrm{sec}\end{array}$ & $\begin{array}{l}72^{\circ} \mathrm{C} \\
45 \mathrm{sec}\end{array}$ & $\begin{array}{c}72^{\circ} \mathrm{C} \\
10 \mathrm{~min} .\end{array}$ & $\begin{array}{c}\text { Dipineto et } \\
\text { al., } 2006\end{array}$ \\
\hline
\end{tabular}

Table 2: primer sequence for Staph. aureus enterotoxins genes used in multiplex PCR (Mehrotra et al., 2000).

\begin{tabular}{|c|c|c|}
\hline Primer pairs & Nucleotide sequence $\left(5^{\prime} \rightarrow 3^{\prime}\right)$ & Amplicon size (bp) \\
\hline $\begin{array}{c}\text { sea } \\
\text { Forward } \\
\text { Reverse }\end{array}$ & $\begin{array}{l}5{ }^{\prime} \text { GGTTATCAATGTGCGGGTGG 3` } \\
5 \text { CGGCACTTTTTTCTCTTCGG 3`}\end{array}$ & 102 bp \\
\hline $\begin{array}{c}s e b \\
\text { Forward } \\
\text { Reverse }\end{array}$ & $\begin{array}{l}\text { 5' GTATGGTGGTGTAACTGAGC } 3 \\
5{ }^{\prime} \text { CCAAATAGTGACGAGTTAGG } 3\end{array}$ & 164 bp \\
\hline $\begin{array}{c}\text { sec } \\
\text { Forward } \\
\text { Reverse }\end{array}$ & $\begin{array}{c}\text { 5'AGATGAAGTAGTTGATGTGTATGG } 3 \\
5^{`} \text { CACACTTTTAGAATCAACCG } 3{ }^{`}\end{array}$ & $451 \mathrm{bp}$ \\
\hline $\begin{array}{c}\text { sed } \\
\text { Forward } \\
\text { Reverse }\end{array}$ & $\begin{array}{c}5 \text { CCAATAATAGGAGAAAATAAAAGG 3 } \\
5 \text { ATTGGTATTTTTTTTCGTTC } 3\end{array}$ & $278 \mathrm{bp}$ \\
\hline $\begin{array}{c}\text { see } \\
\text { Forward } \\
\text { Reverse }\end{array}$ & $\begin{array}{l}\text { 5`AGGTTTTTTCACAGGTCATCC 3` } \\
\text { 5 `CTTTTTTTTCTTCGGTCAATC } 3\end{array}$ & $209 b p$ \\
\hline
\end{tabular}

\section{Statistical analysis:}

The results are expressed as mean \pm standard Error (SE). Data were statistically analyzed using statistical analysis systems.

\section{RESULTS}

Table (1) revealed that, the total aerobic plate count (APC) for chicken nuggets ranged from $1.7 \times 10^{3}$ to $2 \times 10^{4}$ with mean value of $9.1 \times 10^{3} \pm 1.2 \times 10^{3}$, while in beef shawarma $1.2 \times 10^{3}$ to $6.5 \times 10^{4}$ with mean value of $1.3 \times 10^{4} \pm 3.5 \times 10^{3}$. APCs were ranged from $1.3 \times 10^{3}$ to $3 \times 10^{4}$ with mean value of $1.2 \times 10^{4} \pm 2.2 \times 10^{3}$ for Sausage sample Table (2) revealed that chicken nuggets samples were free from coliform. While the coliform counts ranged from $7.0 \times 10^{2}$ to $1.5 \times 10^{3}$ with mean value $1.1 \times 10^{3} \pm 1.2 \times 10^{2}$ in beef shawarma and from $5.0 \times 10^{3}$ to $1.2 \times 10^{4}$ with mean value $8.5 \times 10^{3} \pm 1.1 \times 10^{3}$ in Sausage. From Table (3) Staph. aureus counts ranged from $7.0 \times 10^{2}$ to $65 \times 10^{3}$ with mean value of $6.3 \times 10^{3} \pm 3.1 \times 10^{3}$ in chicken Nuggets ,while in beef shawarma ranged from $3.0 \times 10^{2}$ to $19 \times 10^{3}$ with mean value of $5.6 \times 10^{3} \pm 1.2 \times 10^{3}$, while Staph. aureus counts were ranged from $1.0 \times 10^{3}$ to $2.0 \times 10^{4}$ with mean value $8.7 \times 10^{3} \pm 1.2 \times 10^{3}$ in examined Sausage samples. Table (4) represent the prevalence of Salmonella, E. coli and Staph. aureus microorganisms. Staph. aureus isolated with $10 \%$ from chicken Nuggets sandwiches While in shawarma sandwiches as they constituted $5 \%, 10 \%$ and $15 \%$ for salmonella, E. coli and Staph. aureus respectively. In addition Staph. aureus could be isolated with $15 \%$ of examined sausage sandwiches . Moreover nuggets and sausage sandwiches were negative for Salmonella and E. coli isolation. The isolated strain of Salmonella from beef shawarma sandwiches was serologically identified as S.Typhimurium. 
Table 1: Mean values of APC cfu/g count in examined fast food products.

$(\mathrm{N}=20$ of each)

\begin{tabular}{cccc}
\hline Type of fast food. & Min. & Max. & Mean \pm SE \\
\hline Nuggets & $1.7 \times 10^{3}$ & $2.0 \times 10^{4}$ & $9.1 \times 10^{3} \pm 1.2 \times 10^{3} \mathrm{~A}$ \\
\hline Shawerma & $1.2 \times 10^{3}$ & $6.5 \times 10^{4}$ & $1.3 \times 10^{4} \pm 3.5 \times 10^{3} \mathrm{a}$ \\
\hline Sausage & $1.3 \times 10^{3}$ & $3.0 \times 10^{4}$ & $1.2 \times 10^{4} \pm 2.2 \times 10^{3} \mathrm{a}$ \\
\hline
\end{tabular}

A \& a There were significant differences between the small and capital litter $(P<0.05)$.

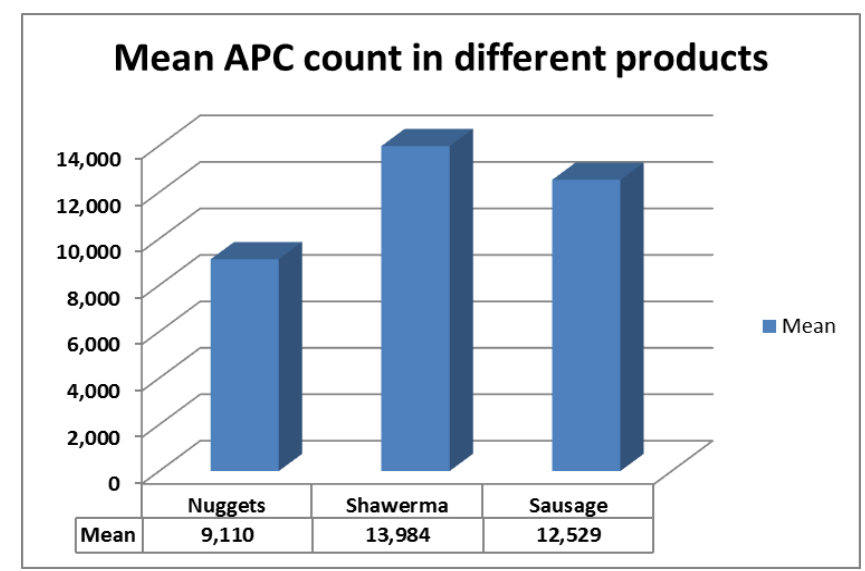

Fig. 1: Mean values of APC count in products

Table 2: Mean values of coliform count $\mathrm{cfu} / \mathrm{g}$ in examined fast food products.

( $N=20$ of each)

\begin{tabular}{cccc}
\hline Type of fast food. & Min. & Max. & Mean \pm SE \\
\hline Nuggets & $<10$ & $<10$ & $<10 \mathrm{~A}$ \\
\hline Shawerma & $7.0 \times 10^{2}$ & $1.5 \times 10^{3}$ & $1.1 \times 10^{3} \pm 1.2 \times 10^{2} \mathrm{aB}$ \\
\hline Sausage & $5.0 \times 10^{3}$ & $1.2 \times 10^{4}$ & $8.5 \times 10^{3} \pm 1.1 \times 10^{3} \mathrm{ab}$ \\
\hline
\end{tabular}

There were a significance differences between capital and small letters $(\mathbf{P}<\mathbf{0 . 0 5})$ within the same column

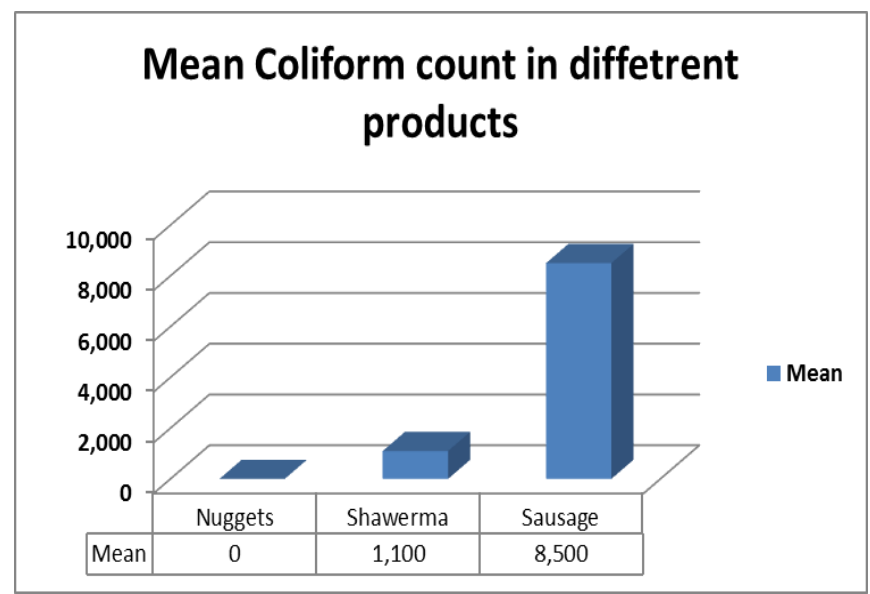

Figure 2: Mean values of coliform count in products.

Table 3: Mean values of Staph. aureus count cfu/g in examined fast food products. ( $\mathrm{N}=20$ of each).

\begin{tabular}{cccc}
\hline Typeof fast food. & Min. & Max. & Mean \pm SE \\
\hline Nuggets & $7^{2} \times \times 10^{2}$ & $65 \times 10^{3}$ & $6.3 \times 10^{3} \pm 3.1 \times 10^{3}$ \\
\hline Shawerma & $3.0 \times 10^{2}$ & $19 \times 10^{3}$ & $5.6 \times 10^{3} \pm 1.2 \times 10^{3}$ \\
\hline Saus age & $1.0 \times 10^{3}$ & $2.0 \times 10^{4}$ & $8.7 \times 10^{3} \pm 1.2 \times 10^{3}$ \\
\hline
\end{tabular}

There no significance difference between three examined product $(\mathbf{P}>\mathbf{0 . 0 5})$ regarding to Staph. aureus count 


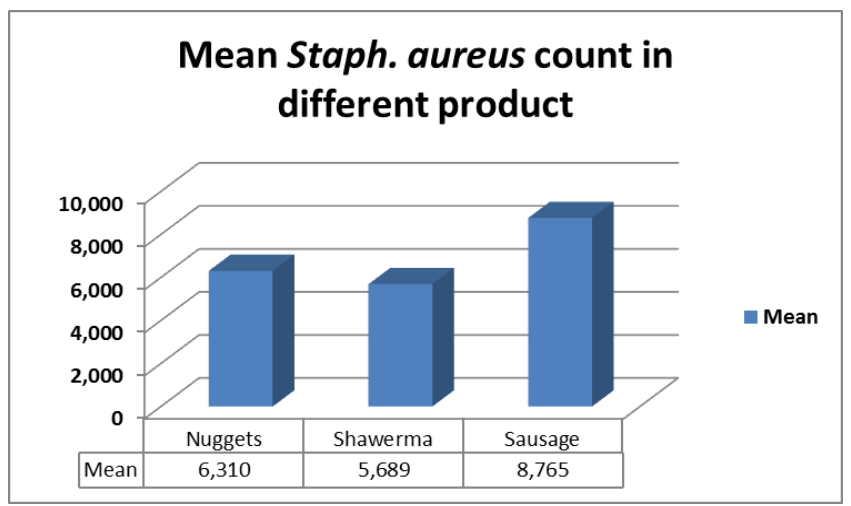

Figure 3: Mean values of Staph. aureus count in products.

Table 4: Incidence of Salmonella, E. coli and Staph. Aureus isolated from examined Nuggets, shawarma and Sausage sandwiches samples $(\mathrm{N}=20$ of each).

\begin{tabular}{cccccccc}
\hline & \multicolumn{6}{c}{ Isolated organisms } \\
\cline { 2 - 7 } Type of Fast food & \multicolumn{3}{c}{ Salmonella } & \multicolumn{1}{c}{ E. coli } & \multicolumn{2}{c}{ Staph. aureus } \\
\cline { 2 - 7 } & No & $\%$ & No & $\%$ & No & $\%$ \\
\hline Nuggets & - & 0.0 & - & 0.0 & 2 & 10 \\
\hline Shawerma & 1 & 5 & 2 & 10 & 3 & 15 \\
\hline Sausage & - & 0.0 & - & 0.0 & 3 & 15 \\
\hline
\end{tabular}

\section{DISCUSSION}

The present study demonstrated that fast food sandwiches samples were contaminated with Salmonella, E. coli and Staphylococcus aureus which indicates a potential breakdown of hygiene at various stages of the food processing and distribution chain.

The result reported in table (1) revealed that, mean value of aerobic plate count (APC) for chicken Nuggets of $9.1 \times 10^{3} \pm 1.2 \times 10^{3}$, while in beef shawarma $1.3 \times 10^{4} \pm 3.5 \times 10^{3}$. And $1.2 \times 10^{4} \pm 2.2 \times 10^{3}$ for Sausage sample there were significant difference between chicken Nuggets and beef shawarma, Sausage sample $(\mathrm{P}<0.005)$ with regarding to APCs. The APCs. were nearly similar to that recorded by Amany et al. (2015) which found that the total aerobic plate count ranged from $6 \times 10^{3}$ to $3.4 \times 10^{5}$ with mean value of $4.8 \times 10^{4}$ $\pm 3.6 \times 10^{3}$ in beef shawarma and lower than that recorded by Nimri et al. (2014) and Odu and Akano, (2012) they found that APCs for shawarma samples were in the range of $2.0 \times 10^{3}$ to $1.8 \times 10^{6} \mathrm{cfu} / \mathrm{g}$.

Despite the use of heat in the preparation of fast food, some pathogenic organisms still present during samples anaylsis. This may be due to the fact that some of the enumerated microorganismes can survive high in cooking temperature to which Shawarma products were exposed which is not sufficient to eliminate harmful microorganisms Abdelhai et al. (2015).

Table (2) Fig No (2) revealed that Nuggets samples were free from coliform. While the coliform mean value $1.1 \times 10^{3} \pm 1.2 \times 10^{2}$ in beef shawarma and $8.5 \times 10^{3} \pm 1.1 \times 10^{3}$ in Sausage. There were a highly significant difference between chicken Nuggets and beef shawarma, Sausage sample $(\mathrm{P}<0.001)$ While significant difference between beef shawarma and Sausage sample $(\mathrm{P}<0.005)$. These results were lower to that recorded by Odu and Akano, (2012) who found that the total coliform count ranged from $1.9 \times 10^{3}$ to $9.4 \times 10^{5}$, for shawarama and higher than recorded by Eman and Sherifa, (2012) who found that coliform count was $3.9 \times 10^{2}$ for shawarama. Elkewaiey, (2012) who found that mean values of APC, total coliforms and total Staphylococcus aureus in chicken nuggets were: $8.2 \times 10^{4} \pm 1.2 \times 10^{4}, 2.4 \times 10^{2} \pm$ $8.0 \times 10$ and $6.0 \times 10^{3} \pm 1.5 \times 10^{3} \mathrm{cfu} / \mathrm{g}$, respectively.

Staphaureus is Gram positive cocci resistant to heat and drying. They produce heat stable enterotoxins that render the food dangerous (Prescott et al., 2005). From table (3) Fig No (3) Mean values of Staph. Aureus were $6.3 \times 10^{3} \pm 3.1 \times 10^{3}$ in chicken Nuggets, $5.6 \times 10^{3} \pm 1.2 \times 10^{3}$ in beef shawarma, while $8.7 \times 10^{3}$ $\pm 1.2 \times 10^{3}$ in examined Sausage samples. (ELMossalami et al., 2009) were 92\%, 80\% and $88 \%$ with mean values of $3.25 \pm 6 \times 10^{3}, 2.8 \pm 1.4 \times 10^{2}$ and $4.1 \pm 2 \times 10^{3} \mathrm{cfu} / \mathrm{g}$. respectively in sausage, beefburger and shawerma and less than (Armany et al., 2016) were $24 \%$ in raw sausage.

Table (4) represent the prevalence of Salmonella, E. coli and Staph. aureus microorganisms. Staph. aureus isolated with $10 \%$ from chicken Nuggets sandwiches While in shawarma sandwiches as they constituted 5 $\%, 10 \%$ and $15 \%$ for salmonella, E. coli and Staph. aureus respectively. In addition Staph. aureus could be isolated with $15 \%$ of examined sausage sandwiches. Moreover nuggets and sausage sandwiches were negative for Salmonella and E. coli 
isolation. The isolated strain of Salmonella from beef shawarma sandwiches was serologically identified as S.Typhimurium. These results were higher than that recorded by (Abdel-Rahman et al., 2011 and Abdalhamid et al., 2013) as they couldn't detect Salmonella in examined sampels on the other hands lower result were obtained by Shahram et al. (2012) who found that Escherichia coli $(40.3 \%)$ was the most prevalent food-borne pathogen isolate followed by Staphylococcus aureus (4.5\%) from 134 fast food sandwiches.

PCR was applied to evaluate the presence of virulence gens in isolated Salmonella, E. coli and Staphylococcus aureus. From Photo No. (1) for isolated Salmonella. Typhimurium were positive invA and $s t n$ virulence genes. invA gene was amplified and detected at 284 bp while stn gene could be detected and amplified at $617 \mathrm{bp}$.

In Korea, Li et al. (2006) could detect 17 virulence genes from isolated Salmonella using PCR assays, 14 genes assayed $(82.4 \%)$ out of these 17 genes included invA gene.

Photo No. (1) showed that neither stx 1 nor stx 2 could be detected in examind two $E$. coli isolates. In contrary Balague et al. (2006) who collected 500 food samples from shops selling ready to eat foods in Argentina and $E$. coli virulence gens were examined by multiplex PCR (stx1, stx2, eae A, cnf 1 , cnf 2 , ein $\mathrm{v}$, $L t 1, S T 1$ and ST11), ten E. coli isolates showed the presence of st 1 , st 2 genes while other genes were negative. Moreover, Bohaychuck et al. (2006) reported shiga toxin producing $E$. coli $\mathrm{O} 22$ : $\mathrm{H} 8$ from beef samples in Alberta, Canada.

Staph. aureus is one the leading causes to food poisoning, its pathogenicity resulted from possession of virulence genes that able to produce different toxins which resulted in self-limiting sever illness. For this reason, the virulence genes of 8 isolated coagulase positive Staph. aureus were examined by PCR and the results showed the presence of enterotoxin producing genes (A,C,D and E) in Staph. aureus isolated strains from nuggets sandwiches, while the three isolates of Staph. aureus isolated from shawarma showed the presence of enterotoxin gene (A) and only one isolates of them showed presence of enterotoxin gene (D). The three isolates of Staph. aureus isolated from sausage the $1^{\text {st }}$ isolate showed presence of enterotoxin genes (B and D), the $2^{\text {nd }}$ isolate showed the presence of enterotoxin gene (D) while $3^{\text {rd }}$ Staph. aureus isolate showed presence of enterotoxin genes ( B) (Photo No. 2).

Staph. aureus enterotoxin were analyzed from ready to eat products including pork ham, chicken cold cuts, pork sausage, salami and pork luncheon meat in a study conducted by Fijalkowski et al. (2016), they found that that the most prevalent enterotoxin genes were sei $(36 \%)$, seln $(32 \%)$ and eta encoding exfoliative toxin A (37\%). Another study conducted by Puah et al. (2016) revealed an incidence of (96.2\%) virulence genes from Staph. aureus isolated from 200 food samples. A total of $30.8 \%$ of the isolates carried $S E$ gene which cause food poisoning. Meanwhile, the most common enterotoxin genes found were $\operatorname{seg}(11.5 \%)$ and $e g c(5.8 \%)$.

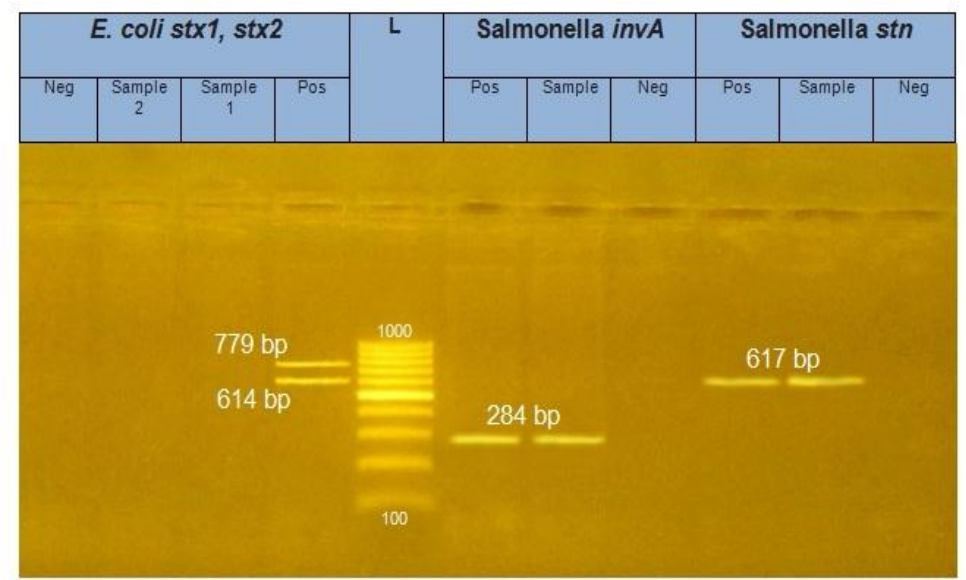

Photo No. (1): Agarose gel electrophoresis of Salmonella and E. coli PCR products using invA, stn, stx1 and st $x 2$ primers.

L= 100 bp DNA ladder.

Neg= negative control.

Pos= positive control (give amplification at 617 pb for stn gene, 284 bp for inv $\mathrm{A}, 614$ bp for stx 1 gene and 779 bp for stx 2 .

isolate (1) and isolate (2) of E. coli isolates were negative.

Salmonella Typhimurium isolate showed 284 bp amplification for invA gene and 617 pb for stn gene. 


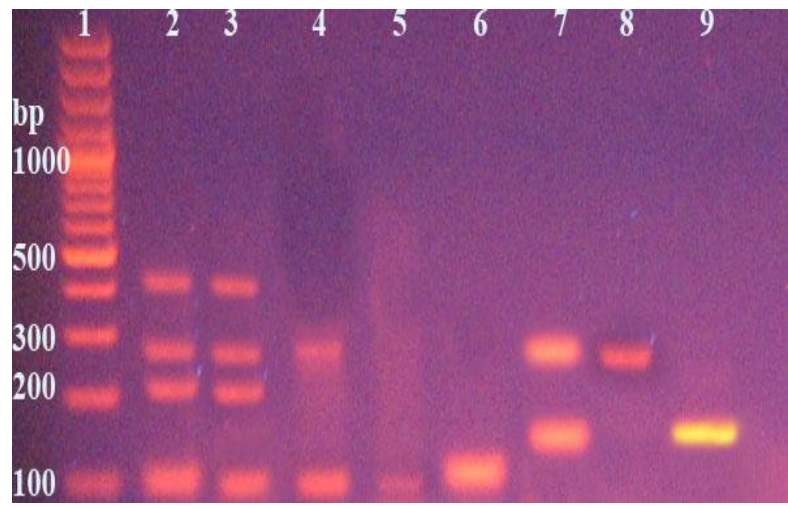

Photo No. (2): Agarose gel electrophoresis of S. aureus PCR products using enterotoxins Staphylococcus primer.

Lane "1": 100 bp DNA ladder

Lane "2 ": positive amplification of 102 bp for enterotoxin A, $209 \mathrm{bp}$ for enterotoxin E, $278 \mathrm{bp}$ for enterotoxin $\mathrm{D}$ and $451 \mathrm{bp}$ for enterotoxin C

Lane "3": positive amplification of 102 bp for enterotoxin A, 209 bp for enterotoxin E, 278 bp for enterotoxin $\mathrm{D}$ and 451 bp for enterotoxin C

Lane "4": positive amplification of $102 \mathrm{bp}$ for enterotoxin A and $278 \mathrm{bp}$ for enterotoxin D

Lane "5": positive amplification of $102 \mathrm{bp}$ for enterotoxin A

Lane "6": positive amplification of 102 bp for enterotoxin A

Lane "7": posistive amplification of $164 \mathrm{bp}$ for enterotoxin B and $278 \mathrm{bp}$ for enterotoxin D

Lane "8": positive amplification of 278 bp for enterotoxin D

Lane "9": positive amplification of 164 bp for enterotoxin B

\section{CONCLUSIONS}

This study confirms that fast food sandwiches may serve as a source of foodborne pathogens and a potential public health hazard. Corrective action needs to be employed to minimize the risk of consuming this type of fast food and we are in need for regular surveillance by the public health regulatory bodies with WHO and ISO standards for food safety. More attention should be given to the cleanliness of utensils used in preparing the sandwiches. In addition to the personal hygiene of the workers preparing and stuffing the sandwiches.

\section{REFERENCES}

Abdalhamid, S.A.; Farj, A.A. and Ali, A.B. (2013): Bacterial Contamination of Ready to Eat Foods (Shawerma Sandwiches) in Misurata City, Libya. 2nd Int. Conf. on Env., Agr. and Food Sci. (ICEAFS'2013) May 6-7, 2013 Kuala Lumpur (Malaysia).

Abdelhai, M.H.; Sulieman, A.M.E. and Babiker, E.R.B. (2015): Some chemical and microbiological characteristics of shawerma meat product. J. Food Nutr. Disor. 4: 2.

Abdel-Rahman, H.A.; Soad, A.S. and Esmail, M.E. (2011): Microbiological Quality of Shawerma at Fast Food Restaurants. SCVMJ, XVI (1).

Angelillo, IF.; Viggiani, NM.; Rizzo, L. and Bianco, A. (2000): Food handlers and food borne disease: knowledge, attitude sand reported behavior in Italy. J Food Prot 63: 381-385.

APHA (2001): American public health association Committee on Microbiological Methods for Foods. Compendium of methods for the microb. exam. of foods. 4.ed. Washington. Egypt. J. Chem. Environ. Health, 1 (1):686693(2015).

Amany M. Ahmed; Nagwa A.B. El-Hakem and Ghada A. Ibrahim (2015): Chemical and microbial assessment of beef and chicken shawarma sandwiches in Ismailia governorate and its impact on consumer health Egypt. J. Chem. Environ. Health, 1 (1): 686-693.

Armany, G.A.; Ibrahim, M. Hemmat; Amin, R.A. and Ahmed, A. Hanaa (2016): Detection of some foodborne pathogens in meat products by Polymerase Chain Reaction.Benha Vet. Med. J. 30, 1; 323-330.

Balague, C.; Khan, A.A.; Fernandez, L.; Redolfi, A.L.; Aquili, V.; Voltattorni, P.; Hofer, C.; Ebner, G.; Duenas, S. and Cerniglia, C.E. (2006): Occurrence of non O157 shiga toxin producing E.coli in ready to eat food from supermarkets in Argentina. Food Microbiol; 23(3): 307-313.

Bohaychuck, V.M.; Gensler, G.E.; King, R.K.; Manninen, K.I.; Sorensen, O.; Wu, J.; Stiles, M.E. and McMullen, L.M. (2006): occurrence of pathogens in raw and ready to eat meat and poultry products collected from the retail 
market place in Edmonton, Alberta, Canada. J food Prot; 69(9): 2176-2182.

Brook, MO.; Smith, RR.; Bannister, BA.; McConnel, M.; Chart, H. and Scotland, SM. (1994): Prospective study of verocytotoxin producing, enteroaggregative and diffusely adherent Escherichia coli in different diarrhoeal states. Epidemiol Infect.112: 63-7.

Dipineto, L.; Santaniello, A.; Fontanella, M.; Lagos, K.; Fioretti, A. and Menna, L.F. (2006): Presence of Shiga toxin-producing Escherichia coli $\mathrm{O} 157: \mathrm{H} 7$ in living layer hens. Letters in Applied Microbiology 43 (2006) 293-295.

Eman, M.S. and Sherifa, M.S. (2012): Microbiological Loads for Some Types of Cooked Chicken Meat Products at Al-Taif Governorate, KSA. World Applied Sci. J. 17 (5): 593-597.

El-Kewaiey I.A: (2012): Quality assessment of some ready - to - eat and locally produced chicken meat product Assiut Vet. Med. J. Vol. 58 No. 132

El-Mossalami, H.H.A.; Abd-EL-Rahman, A.A. and Magdy, E.M. (2009): A study on the effect of Garlic and Nigella sativa on some food poisoning bacteria isolated from ready to- eat meat sandwiches in Alexandria City. Assiut Veterinary Medical Journal. 54; 119, 140-158.

FDA (2002): Food and Drug Administration. Bacteriological Analytical Manual. 9th Ed., AOAC International, Arlington, VA, USA.

Fijalkowski, K.; Peitler, D. and Karakulsuka, J. (2016): Staphylococci isolated from ready to eat meat identification, antibiotic resistance and toxin gene profile. Int $\mathbf{J}$ food Microbiol.; 238: 113-120.

Forbes, A.; Sahm, D. and Weissfield, A. (2002): Diagnostic Microbiology 10th ed. Mosby Inc. 11830 west Line.

ISO, 6579 (2002): Microbiology of Food and Animal Feeding Stuffs-Horizontal Method for the Detection of Salmonella spp.

ISO, 16649/2 (2001): Microbiology of Food and Animal Feeding Stuffs-Horizontal Method for the enumeration of beta -glucuronidasepositive Echerchia coli: part 2: colony-count technique at $44^{\circ} \mathrm{C}$ using 5-bromo -4-chloro-3indoly beta-glucuronide.

ISO, 6887/2 (2003): Microbiology of Food and Animal Feeding Stuffs - Preparation of Test Samples, Initial Suspension and Decimal Dilutions for Microb. Exam Egypt. J. Chem. Environ. Health, 1 (1): 686-693.

Li, Q.; Skyberg, J.A.; Fakhr, M.K.; Sherwood, J.S.; Molan, L.K. and logue, C.M. (2006): antimicrobial susceptibility and characterization of Salmonella isolates from processed Bison carcass. APL Microbiol 72:3046-3049.

Kaneko, K.; Hayashidani, H.; Ohtomo, Y.; Kosuge, J.; Kato, M.; Takahashi, K.; Shiraki, Y. and
Ogauwa, M. (1999): Bacterial contamination of ready to eat foods and fresh products in retail shops and food factories. J. Food and Drug Analysis 1: 105-115.

Mehrotra, M.; Wang, G. and Johnson, M.W. (2000): Multiplex PCR for detection of genes for Staphylococcus aureus enterotoxin, exfoliative toxins, toxic shock syndrome toxin 1, and Methicillin resistance. Journal of Clinical Microbiology, Vol. 38: 1032-1035.

Musa, O.L. and Okande, T.M. (2002): Effect of Health Education Intervention or Food Safety Practice among Food Vendors in Ilorin. J. Med.5: 120-124.

Murugkar, H.V.; Rahman, H. and Dutta, P.K. (2003): Distribution of virulence genes in Salmonella serovars isolated from man \& animals. Indian J Med Res., 117: 66-70.

Nimri, L.; Abu AL-Dahab, F. and Batchoun, R. (2014): Foodborne bacterial pathogens recovered from contaminated shawarma meat in northern Jordan. J Infect Dev. Ctries 2014; 8(11): 1407-1414.

Odu, N.N. and Akano, U.M. (2012): The Microbiological Assessment of Ready-To-EatFood (Shawarma) In Port Harcourt City, Nigeria. Nature and Science 2012; 10(8) p 1-8.

Odumeru, J.; Mitchell, S.; Alves, D.; Lynch, J.; Yee, A.; Wang, S.; Styliadis, S. and Farber, J. (1997): Assessment of the microbiological quality of ready to use vegetables for health care food services. J Fodo Prot 60: 954-960.

Oliveira, S.D.; Rodenbusch, C.R.; Ce, M.C.; Rocha, S.L.S. and Canal, C.W. (2003): Evaluation of selective and non Selective enrichment PCR procedures for Salmonella detection. Lett. Appl. Microbiol., 36: 217-221.

Pelczar, MJ.; Chane, CS. and Kreig, NR. (2006): Microbiology 5th edition. Tata McGraw-Hill Publishing Company Limited, New Delhi.

Prescott, M.; Harley, P. and Klein, D.A. (2005): Microbiology 6th Edtn McGraw Hill. New York U.S.A. p.910.

Puah, S.M.; Chua, K.H. and Tan, J.A. (2016): virulence factor and antibiotic susceptibility of Staphylococcus aureus isolates in ready to eat foods: detection of Staphylococcus aureus contamination and a high prevalence of virulence genes. Int $\mathbf{J}$ Environ Res public health $5 ; 13(2) 199$.

Shahram, Kalantari; Gholamreza, Sepehri; Abbas, Bahrampour and Ehsan, Sepehri (2012): Determination of bacterial contamination isolated from Sandwiches in Kerman City and their resistance to commonly used antimicrobials. Archives of Applied Science Research, 2012, 4 (2): 1100-1105

Uyttendaele, M.; De Troy, $P$. and Debevere, J. (1999): Incidence of Salmonella, Campylobacter jejuni, Campylobacter coli and Listeria monocytogenes in poultry carcasses 
and different types of poultry products for sale on the Belgian retail market. J Food Prot 62: 735- 740 .

Woodward, BB. (1996): Food and residue laboratories. Sited in Lim, C.S.Y. Fernando and Wei C (1996), occurrence of Listeria monocytogenes, Salmonelal spp., Escherichia coli and E. coli 0157: H7 in vegetable salads. Food Control 7: 135-140.1-812.

\section{التوصيف البكتريولوجى والجزيئى لبعض انواع الميكروبات المعزولة من الوجبات السريعه نشوى محد ذكى ، نـهال محمود نبيل ، احد حجازى رمضان ، نـهلة صلاح لبيب الشاطر}

Email: nashwazaki80@gmail.com Assiut University web-site: www.aun.edu.eg

تم إجر اء هذه الدر اسة لعمل تقييم بكتيريولوجى وجزيئى على بعض أنواع البكتيريا الممرضه المعزولة من الوجبات السريعة. حيث تم

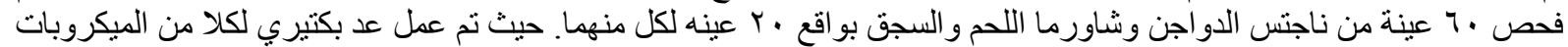

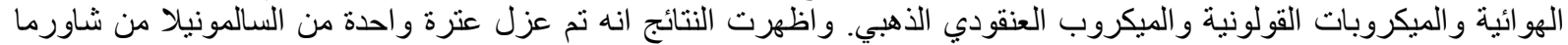

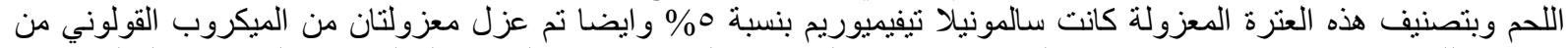

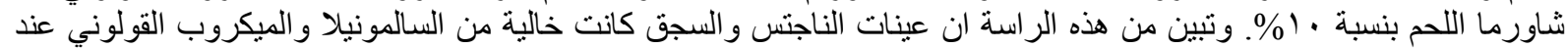

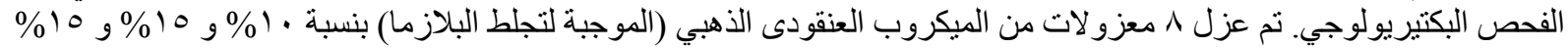

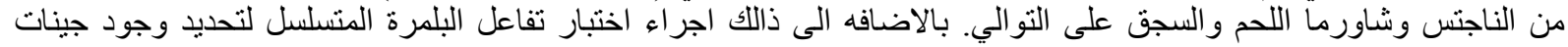

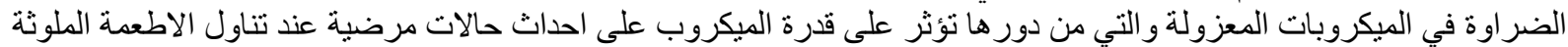

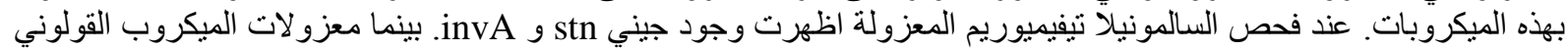

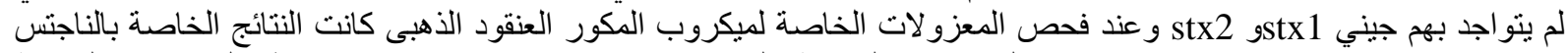

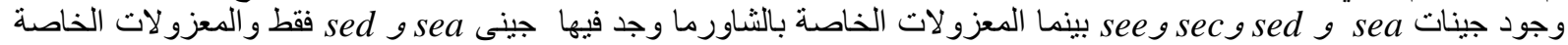

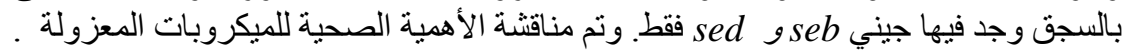

